PROBLEMS

OF MANAGEMENT IN THE $21^{\text {st }}$ CENTURY Vol. 9, No. 1, 2014

\title{
RELATIONSHIPS BETWEEN EMOTIONAL COMPETENCE AND TASK-CONTEXTUAL PERFORMANCE OF EMPLOYEES
}

\author{
Ebru Aykan \\ Erciyes University, Kayseri, Turkey \\ E-mail: aykane@erciyes.edu.tr
}

\begin{abstract}
The present study was conducted to determine the relationships between the emotional competence and task-contextual performance of employees. Data were gathered from 342 employees working in state and private banks. Relationships between the variables, significant relationships between the emotional competence dimensions and performance dimensions were observed in this study. No relationship was observed between the "guilty" dimension of emotional competence and task performance.Non-hierarchical cluster analysis was selected and K-means cluster analysis was performed to determine the emotional competence levels of participant banking professionals. The seven pre-specified emotional competences were classified by using Ward's method. Cluster analysis revealed that the emotional competences of the participants were clustered in two groups as high and low. Regression analyses revealed insignificant relationships between the emotional competence and task performance of employees, but positive significant relationships between emotional competence and contextual performance. Significant differences were also observed in the emotional competence levels and task-contextual performances of employees. In other words, individuals with high emotional competence levels also exhibited high performances.
\end{abstract}

Key words: contextual performance, emotional competence, task performance.

\section{Introduction}

People find themselves in complex relations as a result of the rapid pace of modern day living. They experience problems in expressing their feelings and problems, especially in their daily working lives. In such a busy pace, the peace and happiness of individuals and of organizations totally depend on the mutual mental and emotional understanding of individuals. Emotions are internal guides leading individuals in communications in response to signals coming from their surroundings (Goleman 1996, 1998). Emotional competence is usually reflected by recognition of self-emotions, postponing desires, showing resistance against hurdles, approaching others in an appreciative manner and by getting into and sustaining efficient relations. Such competences provoke the success and satiation of an individual in his/her daily life (Acar, 2001). Emotionally-competent individuals can easily overcome the unexpected emotional phenomenon. Most of the time they get respect as a member of the social community and are successful in daily issues (Saarni, 1999).

Organizations mostly focus on human resources, the key element, in order to achieve a sustainable competitive advantage. Thus, they search for methods to improve the motivation and performance of employees and consequently to improve business efficiency and productivity. They usually try to employ individuals with relevant professional knowledge, experience and skills and to provide a physical, social and emotional inner-organizational environment in which those individuals may perceive themselves as an internal component of the organization. Then those happy employees, with the physical, social and emotional support of the organization behind them, exhibit higher commitment and improved performance (Doğan, 2005). 
The service sector, with its special characteristics, is a type of business which creates a high level of stress both in managers and employees. The banking sector, in particular, is a manpower-oriented service sector and creates excessive stress in employees because the service is not standardized or tangible and requires intensive human relations, high-level precaution, attention, concentration and long-working hours. Therefore, banking professionals should recognize emotions in themselves, their colleagues and customers, should evaluate such emotions and should develop proper responses through reflecting their emotional energy into their daily and working lives (Cooper and Sawaf, 1997). Emotional competences come to the forefront here as a critical issue for providing a better service by banking professionals to their customers and better performance for their organizations. In this context, the present study was conducted to investigate the relationships between the emotional competences and performances of banking professionals. Initially the concepts of emotional competence and performance are briefly defined and evaluated, and then the practical sections of the study are presented.

\section{Emotional Competence}

Emotional competence refers to a set of skills used to perceive one's feelings and other's emotions, to regulate them, and to use this information to guide one's thinking and actions (Mayer and Salovey, 1997; Kim et al. 2009). In other words, emotional competence determines how we manage ourselves. Goleman (1995) expresses emotional competence as an indicator of the emotional intelligence of individuals and evaluates it within the scope of personal and social competences. Personal competences express the competences required to exhibit constructive behaviors complying with the role of individuals both in their social and work lives. On the other hand, social competences express the competences specifying the nature and success of an individual's personal relations.

From another point of view, emotional competence is defined as the characteristics and abilities guiding and orienting the emotional practices of individuals, and most of the time it is considered as the integration of emotional intelligence-based learnable characteristics yielding superior performance in work life (Verbeke et al. 2004). Employees with a high level of emotional competence in an organization are able to the integrate abilities and skills required to manage varying emotional cases in the working environment (McAdams, 1988) and they usually focus on positive outcomes for both themselves and their organizations.

Emotional competence is conceived as the integration of seven seemingly unrelated proficiencies (Verbeke et al. 2004; Vij et al. 2010). These are as follows: perspective taking (the skill of putting oneself in the place of another), managing self-presentations of emotion (this is person's type, different awareness that expression of her/his emotions affects others (Saarni, 1999)), helping others to accept their emotions (understanding and helping others when their feelings are different from those they wish to express) (Morris and Feldman, 1996)), dissociation of guilt from strategic intent (skills in the strategic management of emotions will come to naught if the communicator counterfactually anticipates self-guilt in their use), feeling of authenticity (proper and organization-specific communication rules to develop the skills of individuals), an ironic perspective (irony is achieved through a willingness to let go of conventional ways of viewing an experience, and to try new vocabularies and interpretive routines) and the role of personal norms (emotional reactions of individuals shaped around their own moral norms and ethical values).

In this context, emotional competences, in brief, express all skills and abilities which help individuals in creating a balance in an emotional sense between themselves and their surroundings. The seven above-specified competences are combined together to create individualspecific emotional competence. Therefore, each individual has specific and different competence levels. 
PROBLEMS

OF MANAGEMENT

IN THE $21^{\text {st }}$ CENTURY Vol. 9, No. 1, 2014

10

\section{Relationships between Emotional Competence and Task-Contextual Performance}

Recent studies revealed that businesses tend towards activities which create a difference/value for their success. Creation of a difference/value is only possible through the human resources of the businesses. Performance is envisaged as the very basic success indicator of human resource and improved performance is the basic means of providing business efficiency and productivity. Performance, in the most general sense, expresses the outcomes achieved by an employee through performing a task assigned to him/her in a specified timeframe (Doğan, 2005). The concept of performance has a multi-dimensional nature (Borman and Motowidlo, 1993). Among these dimensions, two in particular have attracted the attention of researches: Task performance and contextual performance (Borman and Motowidlo, 1993; Motowidlo et al. 1997). While task performance expresses the expertise in job requirements defined officially as the activities part of the business (Borman and Motowidlo, 1993), contextual performance expresses behavior patterns supporting the psychological and social contexts of job activities (Borman and Motowidlo, 1997).

Reflections of emotions on work performance are usually evaluated under two different behavior dimensions. The first covers the behavior of individuals as required by their jobs, while the second covers the emotion-oriented behavior of individuals. Such behaviors confront organizations with three different cases (Weiss and Cropanzano, 1996; Doğan, 2005): Emotional reactions may reduce performance through creating reactions incompatible with the requirements of the job; emotional reactions may improve performance through complying with the requirements of the job; there may not be any relationships between emotion-related behaviors and job performance-related behaviors. In previous studies, linear relationships were generally observed between emotions and work performance (Sala, 2000; Doğan, 2005; Mishra and Mohapatha, 2010). Similarly, linear relationships were also observed between the emotional competence and work performance of employees (Verbeke et al., 2004; Jayan, 2006; Kim et al., 2009; Araujo and Taylor, 2012).

This study is needed because the researches relevant to the relationships between emotional competence and task-contextual performance of employees are limited. The research objective of this study is to investigate the relationship between the emotional competence and task-contextual performance of employees. The following hypothesis will be tested in this respect:

H1: Banking professionals will differ in the emotional competence so that the pattern of response to measures of the seven proficiencies will yield clusters of banking professionals.

H2: There is a positive significant relationship between the emotional competences and task performance of banking professionals.

H3: There is a positive significant relationship between the emotional competences and contextual performance of banking professionals.

H4: Emotionally competent banking professionals will achieve higher level of task-contextual performance than less emotionally competent banking professionals.

In this sense, the aim of the present study is to determine the relationships between emotional competences and task-contextual performances of banking professionals.

\section{Methodology of Research}

\section{Sample of Research}

State and private banks operating in the Kayseri/Melikgazi region constituted the research universe. Within the scope of the study, questionnaire forms were delivered to employees working in those banks. Of those employees (552), 342 yielded evaluable questionnaires. The questionnaire response rate was $61.95 \%$. 


\section{Instrument and Procedures}

The scales used to determine the relationships between the emotional competence levels and work performance of banking professionals are provided below. Research data were gathered through two-section questionnaire forms composed of (5) questions and (39) statements. The first section includes questions about the demographic characteristics of the participants and the second section contains the statements inquiring about the social and emotional competence levels, task and contextual performances of the participants. The research variables were gathered using two scales:

1. Emotional Competence: The "emotional competence scale" developed by Saarni (1999) and consisting of 17 statements was used. The Cronbach's Alpha cofficent was 0.85 .

2. Task and contextual performance: A simplified version of the scale created by adding 9 task performance questions of Goodman and Svyantek'in (1999) to questionnaire of Smith, Organ and Near (1983), was used to measure the task and contextual performance of participants. There were 8 statements to measure task performance and 14 statements to measure contextual performance. Performance statements were evaluated with a 5-point Likert scale with 1 indicating "never" and 5 indicating "always". The Cronbach's Alpha were 0.85 (contextual performance) and 0.91 (task performance). In general, a value of 0.70 in the Cronbach's Alpha is considered adequate in order to ensure reliability of the internal consistency of a scale (Nunnaly, 1978).

\section{Data Analysis}

Dimensions of emotional competence were initially determined through confirmatory factor analysis to evaluate the research data. Then, cluster analysis was performed to determine the emotional competence levels of employees. Regression analysis and t-tests were finally performed to determine the differences and relationships between emotional competence levels and performance dimensions.

\section{Results of Research}

\section{Demographic Characteristics}

Frequency and percentage values about the demographic characteristics of research participants are provided in Table 1. 
PROBLEMS OF MANAGEMENT IN THE $21^{\text {st }}$ CENTURY Vol. 9, No. 1, 2014

Table 1. Demographic Characteristics, Frequency and Percent Distributions $(\mathrm{N}=342)$.

\begin{tabular}{|c|c|c|c|c|c|}
\hline Characteristics & Frequency & $\%$ & Characteristics & Frequency & $\%$ \\
\hline Gender & & & Age & & \\
\hline Female & 137 & 40.1 & $21-30$ years & 135 & 39.5 \\
\hline \multirow[t]{3}{*}{ Male } & 205 & 59.9 & $31-40$ years & 158 & 46.2 \\
\hline & & & $41-50$ years & 38 & 11.1 \\
\hline & & & $51+$ & 11 & 3.2 \\
\hline \multirow[t]{2}{*}{ Education } & & & Position & & \\
\hline & 45 & 13.2 & & 40 & \\
\hline High school & 7 & 2.0 & Manager & 26 & 7.6 \\
\hline Vocational College & 248 & 72.5 & Vice manager $/ 2^{\text {nd }}$ & 11 & 11.7 \\
\hline Undergraduate & 42 & 12.3 & Manager & 265 & 3.2 \\
\hline \multirow[t]{2}{*}{ Graduate } & & & Expert & & 77.5 \\
\hline & & & Bank clerk & & \\
\hline
\end{tabular}

As is seen in Table 1, 40.1\% of participants were female and $59.9 \%$ were male. A large portion of participants were university graduates $(72.5 \%)$, between the ages of $20-40(87.5 \%)$ and worked as bank clerks (77.5\%).

\section{Mean Values of Research Variables and Correlation Table}

The means and standard deviations of dependent and independent research variables are presented in Table 2. Table 2 reports means, standard deviations, correlations among variables and Cronbach's alpha coefficients. With regard to relationships between the variables, significant relationships were observed between the emotional competence dimensions and performance dimensions at the $\mathrm{p}<0.001$ level. No relationship was observed between the "guilty" dimension of emotional competence and task performance.

Table 2. Descriptives Statistics and Inter-correlations among Study Variables.

\begin{tabular}{|c|c|c|c|c|c|c|c|c|c|c|c|c|}
\hline Variables & Mean & $\begin{array}{l}\text { St. } \\
\text { Dev. }\end{array}$ & 1 & 2 & 3 & 4 & 5 & 6 & 7 & 8 & 9 & 10 \\
\hline 1. Empathy & 3.82 & 0.81 & 1 & & & & & & & & & \\
\hline 2. Guilty & 3.22 & 0.87 & $0.277^{*}$ & 1 & & & & & & & & \\
\hline 3. Authenticity & 3.51 & 0.86 & $0.361^{*}$ & $0.372^{*}$ & 1 & & & & & & & \\
\hline $\begin{array}{l}\text { 4. Self-Presen- } \\
\text { tation }\end{array}$ & 3.58 & 0.81 & $0.363^{*}$ & $0.400^{*}$ & $0.463^{*}$ & 1 & & & & & & \\
\hline $\begin{array}{l}\text { 5. Convincing } \\
\text { others that one } \\
\text { is genuine }\end{array}$ & 3.66 & 0.72 & $0.438^{*}$ & $0.225^{*}$ & $0.251^{*}$ & $0.444^{*}$ & 1 & & & & & \\
\hline 6. Irony & 3.63 & 0.83 & $0.349^{*}$ & $0.248^{*}$ & $0.156^{*}$ & $0.295^{*}$ & $0.543^{*}$ & 1 & & & & \\
\hline 7. Character & 3.92 & 0.74 & $0.303^{*}$ & $0.248^{*}$ & $0.308^{*}$ & $0.330^{*}$ & $0.415^{\star}$ & $0.358^{*}$ & 1 & & & \\
\hline $\begin{array}{l}\text { 8. Emotional } \\
\text { competence }\end{array}$ & 3.62 & 0.55 & $0.615^{*}$ & $0.559^{*}$ & $0.562^{*}$ & $0.653^{*}$ & $0.730^{*}$ & $0.722^{*}$ & $0.592^{*}$ & 1 & & \\
\hline $\begin{array}{l}\text { 9. Task per- } \\
\text { formance }\end{array}$ & 4.06 & 0.65 & $0.437^{*}$ & 0.031 & $0.218^{*}$ & $0.243^{*}$ & $0.441^{*}$ & $0.348^{*}$ & $0.330^{*}$ & $0.421^{*}$ & 1 & \\
\hline $\begin{array}{l}\text { 10.Contextual } \\
\text { performance }\end{array}$ & 3.85 & 0.64 & $0.426^{*}$ & $.105^{\star}$ & $0.240^{*}$ & $0.283^{*}$ & $0.430^{*}$ & $0.378^{*}$ & $0.376^{*}$ & $0.498^{*}$ & $0.730^{*}$ & 1 \\
\hline
\end{tabular}

$$
{ }^{*} \mathrm{p}<0.001
$$


Factor analysis revealed 7 factors with a factor loading value of over 0.50 . Current findings support the results of Verbeke et al. (2004) and also support five of the emotional competences of Vij et al. (2010). Differences were observed only in "guilty" and "convincing others that one is genuine" dimensions.

Table 3. Competencies of Emotional Competence (Factor Loading and Reliabilities).

\begin{tabular}{|c|c|c|c|c|c|c|}
\hline \multicolumn{7}{|c|}{ Emotional Competence } \\
\hline Empathy & Guilty & Authenticity & Self-Presentation & $\begin{array}{l}\text { Convincing } \\
\text { others that one } \\
\text { is genuine }\end{array}$ & Irony & Character \\
\hline $\begin{array}{l}\operatorname{Ec} 1(0.73) \\
\operatorname{Ec} 2(0.52)\end{array}$ & $\begin{array}{l}\operatorname{Ec} 3(0.78) \\
\operatorname{Ec} 4(0.75)\end{array}$ & $\begin{array}{l}\operatorname{Ec5}(0.82) \\
\operatorname{Ec6}(0.81)\end{array}$ & $\begin{array}{l}\operatorname{Ec} 7(0.80) \\
\operatorname{Ec} 8(0.69)\end{array}$ & $\begin{array}{l}\operatorname{Ec9}(0.73) \\
\operatorname{Ec} 10(0.59) \\
\operatorname{Ec} 11(0.52)\end{array}$ & $\begin{array}{l}\operatorname{Ec12}(0.82) \\
\operatorname{Ec13}(0.81) \\
\operatorname{Ec14}(0.79) \\
\operatorname{Ec} 15(0.78)\end{array}$ & $\begin{array}{l}\text { Ec16(0.82) } \\
\text { Ec17(0.68) }\end{array}$ \\
\hline \multicolumn{7}{|l|}{ Reliabilities } \\
\hline 0.84 & 0.75 & 0.72 & 0.69 & 0.62 & 0.86 & 0.61 \\
\hline \multicolumn{7}{|c|}{ Explained Total Variance: 72.04} \\
\hline KMO: 0.848 & & & & & & \\
\hline
\end{tabular}

\section{Hypothesis Testing}

Non-hierarchical cluster analysis was selected and K-means cluster analysis was performed to determine the emotional competence levels of participant banking professionals. The seven pre-specified emotional competences were classified by using Ward's method. The results of cluster analysis are provided in Table 4 . Cluster analysis revealed that the emotional competences of the participants were clustered in two groups as high and low. While 188 of the participants had high emotional competence levels, 139 of them had low emotional competence levels. The result supported H1.

Table 4. Results of Cluster Analysis.

\begin{tabular}{lllllllll}
\hline Cluster & $\begin{array}{l}\text { Number } \\
\text { of Cases } \\
\text { in each } \\
\text { cluster }\end{array}$ & $\begin{array}{l}\text { Empa- } \\
\text { thy }\end{array}$ & Guilty & $\begin{array}{l}\text { Authentic- } \\
\text { ity }\end{array}$ & $\begin{array}{l}\text { Self-Pres- } \\
\text { entation }\end{array}$ & $\begin{array}{l}\text { Convincing } \\
\text { others that one } \\
\text { is genuine }\end{array}$ & Irony & Character \\
\hline High EC & 188 & 4.19 & 3.60 & 3.91 & 3.97 & 3.95 & 3.97 & 4.16 \\
\hline Low EC & 139 & 3.81 & 2.73 & 3.00 & 3.04 & 3.28 & 3.14 & 3.59 \\
\hline Total & 327 & & & & & & & \\
\hline
\end{tabular}

Table 5 presents regression analysis and Beta factor $(\beta=0.421)$ to test the hypothesis. The effect of task performance on the emotional competence was determined as $17.7 \%$. The positive beta value indicates linear relationship. The hypothesis $\mathrm{H} 2$ was accepted. 
PROBLEMS

OF MANAGEMENT IN THE $21^{\text {st }}$ CENTURY Vol. 9, No. 1, 2014

Table 5. Results of Regression Analysis Performed to Determine the Effects of Emotional Competence on Task Performance.

\begin{tabular}{lllll}
\hline Dependent Variable & Beta & $\begin{array}{l}\text { Standard } \\
\text { Error }\end{array}$ & $\mathbf{t}$ & $\mathbf{p}$ \\
\hline Task Performance & $0.421^{*}$ & 0.043 & 8.30 & 0.00 \\
\hline $\mathrm{F}$ & 68.98 & & \\
\hline Adjusted R & 0.175 & & \\
\hline $\mathrm{R}^{2}$ & 0.177 & & \\
\hline Standard Error of Estimation & 0.51 & & \\
\hline Significant & 0.00 & & \\
\hline & $\mathrm{p}<0.00$, Dependent Variable: Emotional Competence
\end{tabular}

Table 6 revealed that the emotional competence was able to explain $24 \%$ of contextual performance at 0.00 significance level. The relationship was positive $(\beta=0.498)$, indicating increasing contextual performances of employees with increasing emotional competences. Within the scope of these results, the hypothesis H3 was accepted.

Table 6. Results of Regression Analysis Performed to Determine the Effects of Emotional Competence on Contextual Performance.

\begin{tabular}{lllll}
\hline Dependent Variable & Beta & $\begin{array}{l}\text { Standard } \\
\text { Error }\end{array}$ & $\mathbf{t}$ & $\mathbf{p ~}$ \\
\hline Task Performance & $0.498^{*}$ & 0.041 & 10.97 & 0.00 \\
\hline $\mathrm{F}$ & 101.95 & & & \\
\hline Adjusted $\mathrm{R}^{2}$ & 0.246 & & & \\
\hline $\mathrm{R}^{2}$ & 0.248 & & & \\
\hline Standard Error of Estimation & 0.46 & & & \\
\hline Significant & 0.00 & & \\
\hline p $<0.00$, Dependent Variable: Emotional Competence
\end{tabular}

We were investigating the predictive validity of the emotional competency clusters. That is, we checked the influence of cluster membership on task-contextual performance. The t-test was performed to determine that emotionally competent banking professionals will achieve higher level of task-contextual performance than less emotionally competent banking professionals. Table 7 provides the results of t-test.

Table 7 revealed that the task and contextual performances of participating banking professionals exhibited significant differences based on their emotional competence $(p<0.00)$. Table 7 shows that emotionally competent banking professionals achieve significantly higher scores on the low emotionally compotent. In other words, participants with high emotional competence had higher task performance $(4.14>3.91)$ and contextual performance $(4.01>3.62)$ than those with low emotional competence. Based on these results, the hypothesis $\mathrm{H} 4$ was accepted. 
Table 7. Means Differences for Performance Parameters (t-test).

\begin{tabular}{|c|c|c|c|c|c|c|}
\hline & & $\mathrm{N}$ & Mean & SD & $t$ & $p$ \\
\hline \multirow{2}{*}{ Task Performance } & High EC & 184 & 4.14 & 0.48 & \multirow{2}{*}{3.24} & \multirow{2}{*}{0.00} \\
\hline & Low EC & 138 & 3.91 & 0.81 & & \\
\hline \multirow{2}{*}{ Contextual Performance } & High EC & 178 & 4.01 & 0.43 & \multirow{2}{*}{5.65} & \multirow{2}{*}{0.00} \\
\hline & Low EC & 133 & 3.62 & 0.79 & & \\
\hline
\end{tabular}

\section{Discussion}

It is highly significant that employees should feel themselves emotionally sufficient while they are working in an organization. Especially in labor-intensive businesses and service sectors, employees are in communication with customers all day long and such intensive communications create significant physical, mental and emotional stress in employees. Such stress also affects the emotions of individuals. Various studies have been in particular, carried out about emotions in organizational life since the 1930s. These studies investigated, in particular the impacts of emotions on perceptions, attitudes and behaviors. In the 1990s, in addition to emotions, the concepts of emotional intelligence and consequent emotional competences were introduced.

Emotional competence expresses the style of an individual in managing emotions through various skills. Management of emotions in social environments may require totally overcoming complex and ambiguous cases and personal incompatibilities. In the banking sector, in particular, employees dealing with accounting works at any time should exhibit proper perception, understanding and attitude towards their customers in their tangible processes. Thus, banking professionals should have high emotional competence levels to provide customer satisfaction.

The present study was conducted initially to determine that banking professionals will differ in emotional competence so that the pattern of response to measures of the seven proficiencies will yield clusters of banking professionals. Cluster analysis revealed that research participants were clustered in two emotional competence groups as of high and low. Only one study was found in the literature about emotional competence levels. Verbeke et al. (2004) classified emotional competence levels of salespersons into four groups as of those with high emotional competence levels, those with low emotional competence levels, the emotionally unstable group and the low irony group. Thus, current emotional competence levels are somewhat different from those defined in Verbeke et al. (2004). Such differences were mainly because of the different professional groups in the studies.

The other objective of the present study was to determine the relationships between the emotional competences and work performances (task and contextual performance) of participants. According to regression analysis, there were significant relationships between emotional competences and task and contextual performance of participants $(p>0.00)$. In literature, the studies inquiring the relationships between the emotional competence and performance usually took only one dimension of work performance into consideration. In this sense, the positive relationship observed in the present study between emotional competence and two dimensions of work performance supports the findings of Verbeke et al. (2004), Jayan (2006), Kim et al. (2009), Mishra and Mohapatha (2010), Clarke and Mahadi (2011) and Araujo and Taylor (2012). Additionally the high emotionally competent banking professionals achieve significantly higher scores on the low emotionally compotent. Such findings also support the results of Verbeke et al. (2004). In other words, individuals with high emotional competence also had higher performances. 
PROBLEMS

OF MANAGEMENT

IN THE $21^{\text {st }}$ CENTURY Vol. 9, No. 1, 2014

16

\section{Conclusions}

To conclude, the relationships between the emotional competences and performances of banking professionals were investigated in this study. Based on the above provided information and current findings, individuals working in businesses requiring intensive communications with people should have emotional competences including integration of emotion management functions. As much as the working environment, efficient and productive performance of employees depend also on feelings of emotional self-sufficiency in that environment. In this sense, the success of businesses is shaped around the emotional competence development potentials of their employees. At this point in time, the task assigned to organizations is to provide relevant training for the awareness and development of emotional competences against unexpected emotional situations arising developing within or around the employee.

There are some limitations to the present study. Problems may be experienced in generalization of the outcomes since the study was performed in a single professional group and in a small sample. Also, coverage of a single region may also be considered as a limitation.

The relationship between the emotional competence and work performance was taken as the basis of this study. In future studies, the relationships among emotional competences and job satisfaction, organizational commitment, organizational citizenship-like business outcomes may be investigated and service quality and customer satisfaction-like issues may also be included.

\section{References}

Acar, F. T. (2001). Duygusal zeka yeterliliklerinin göreve yönelik ve insana yönelik liderlik davranışları ile iliş̧kisi: Banka şube müdürleri üzerinde bir araştırma. İstanbul Üniveristesi Sosyal Bilimler Enstitüsü. Yayınlanmamış Doktora tezi. İstanbul.

Araujo, S. V. A., Taylor, S. N. (2012). The influence of emotional and social competencies on the performance of Peruvian refinery staff. Cross Cultural Management, 19 (1), 19-29.

Borman, W. C., \& Motowidlo, S. J. (1993). Expanding the criterion domain to include elements of contextual performance. In N. Schmitt \& W. C. Borman Ws. Personnel selection in organizations. Jossey-Bass. San Francisco.

Cooper, R. K., \& Sawaf, A. (1997). Executive EQ: Emotional intelligence in leadership and organisations. Grosset/Putnum. New York.

Doğan, Y. (2005). Duygusal olaylar teorisi çerçevesinde negatif ve pozitif duygusallığın çalışanların görev ve bağlamsal performansları üzerindeki etkisini belirlemeye yönelik Kayseri'de bir araştırma. Erciyes Üniveristesi Sosyal Bilimler Enstitüsü. Yayınlanmamış Doktora tezi. Kayseri.

Goleman, D. (1995). Emotional intelligence: Why it can matter more than IQ. New York: Bantam Books.

Goleman, D. (1998). Working with emotional intelligence. New York: Bantam Books.

Jayan, C. (2006). Emotional competence, personality, and job attitudes as predictors of job performance. Journal of the Indian Academy of Applied Psychology, 32 (2), 135-144.

Kim, T. Y., Cable, D. M., Kim, S. P., Wang, J. (2009). Emotional competence and work performance: The mediating effect of proactivity and the moderating effect of job autonomy. Journal of Organizational Behavior, 30 (7), 983-1000.

Mayer, J. D., \& Salovey, P. (1997). What is emotional intelligence? In Salavey. P. \& Sluyter. D. (Eds.). Emotional development and emotional intelligence. Basic Books. New York, 3-31.

Mishra, P. S., \& Mohapatra, A. K. D. (2010). Relevance of emotional intelligence for effective job performance: An empirical study. Vikalpa, 35 (1), 53-61.

Morris, J. A., \& Feldman, D. C. (1996). The dimensions, antecedents, and consequences of emotional labor. Academy of Management Review, 21 (4), 986-1010.

Motowidlo, S. J., Borman, W. C., Schmit, M. J. (1997). A theory of individual differences in task and contextual performance. Human Performance, 10, 71-83.

Nunnaly, J. C. (1978). Psychometric Theory, 2nd edn. McGraw-Hill, New York.

Saarni, C. (1999). The develpoment of emotional competence. A Division of Guildford Publications Inc.. New York. 
Sala, F. (2000). It's lonely at the top: Executives emotional intelligence self (mis) perceptions. Consortium for Research on Emotional Intelligence in Organizations. http://www.eiconsortium.org/pdf/ executive_emotional_intelligence360.pdf.

Verbeke, W., Belschak, F., Bagozzi, R. P. (2004). Exploring Emotional Competence: Its effects on coping, social capital, and performance of salespeople. Social Science Research Network, Tomorrow's Research Today, 1-59. http://repub.eur.nl/pub/1174/ERS\%202004\%20014\%20ORG.pdf.

Vij, S., Sharma, R., Sharma, M. K. (2010). A study of identifying the emotional competence of Indian salespeople. The IUP Journal of Marketing Management, 9 (3), 24-40.

Weiss, H. M., \&Cropanzano, R. (1996). Affective events theory: A theoretical discussion of the structure. Cases and consequences of affective experiences at work. Research in Organizational Behavior, $18,1-74$.

Advised by Mustafa Kacur, Erciyes University, Kayseri, Turkey

Received: February 05, 2014

Accepted: April 28, 2014

Ebru Aykan

Assistant Professor, Erciyes University, School of Applied Sciences, Human Resource Management Department, 38039, Kayseri, Turkey.

Phone: +90 352 2076666-43569.

E-mail: aykane@erciyes.edu.tr 